\title{
Progressive subacute combined degeneration: a severe relapse with dis- continuation of vitamin B12 treatment
}

\author{
Progresif subakut kombine dejenerasyon: B12 vitamini tedavisinin bırakılmasıyla oluşan \\ şiddetli bir nüks olgusu
}

Feyza Ünlü Özkan, ${ }^{1}$ Meryem Yılmaz Kaysın, ${ }^{1}$ Fatma Nur Soylu Boy, ${ }^{2}$ Işl Üstün, ${ }^{3}$ İlknur Aktaş ${ }^{1}$

${ }^{1}$ Department of Physical Medicine and Rehabilitation, Fatih Sultan Mehmet Training and Research Hospital, İstanbul, Turkey

${ }^{2}$ Department of Radiology, Fatih Sultan Mehmet Training and Research Hospital, İstanbul, Turkey

${ }^{3}$ Department of Physical Medicine and Rehabilitation, Bağclar Training and Research Hospital, İstanbul, Turkey

Received / Geliş tarihi: June 2014 Accepted / Kabul tarihi: December 2014

\begin{abstract}
Subacute combined degeneration is a rare clinical manifestation characterized by dysesthesia, deep sensory impairment and spastic paraparesis. A 62 -year-old male patient was admitted to the outpatient clinic with the complaint of difficulty in walking. We detected he had position and vibration loss in all extremities, bilateral weakness in legs, spasticity and increase in deep tendon reflexes. History of the patient revealed that he was previously examined in a neurology clinic for sensory disturbance and his complaints declined after vitamin B12 deficiency was detected and treated. Following the discontinuation of treatment, we took the patient admitted to our clinic with spastic paraplegia to the inpatient physical therapy program and we applied B12 replacement; we follow-up the patient who can ambulate with the aid of a walker upon discharge.
\end{abstract}

Keywords: Paraparesis; subacute combined degeneration; vitamin B12.

$\ddot{O Z Z}$

Subakut kombine dejenerasyon dizestezi, derin duyu bozukluğu ve spastik parapareziyle karakterize nadir bir klinik tablodur. Altmış iki yaşında erkek hasta polikliniğe yürüme güçlüğü yakınmasıyla başvurdu. Tüm ekstremitelerde pozisyon ve vibrasyon kaybı, bacaklarda iki taraflı güçsüzlük, spastisite ve derin tendon reflekslerinde artış saptandı. Hastanın öyküsünden duyusal yakınmalar nedeniyle daha önce nöroloji kliniğinde incelendiği, B12 vitamini eksikliği saptanarak tedavi uygulandığı ve yakınmalarının gerilediği öğrenildi. Tedaviyi bırakmasının ardından spastik parapleji tablosu ile polikliniğimize başvuran hasta yatarak fizik tedavi programına alındı ve B12 replasmanı uygulandı, taburculuğunda walker ile ambule olabilen olgu takibe alındı.

Anabtar sözcükler: Paraparezi; subakut kombine dejenerasyon; B12 vitamini.

Subacute combined degeneration (SCD) is a rare neurological complication of vitamin B12 deficiency, characterized by the demyelination of dorsal and lateral spinal cord. Clinical manifestations of SCD are symmetric dysesthesia, disturbance of position sense and spastic paraparesis or tetraparesis. Vitamin B12 deficiency causes a wide range of hematological, gastrointestinal, psychiatric and neurological disorders. The most consistent magnetic resonance imaging (MRI) finding is a symmetrical abnormally increased $\mathrm{T}_{2}$ signal intensity confined to posterior or posterior and lateral columns in the spinal cord. We report a case with progressive SCD due to vitamin B12 deficiency. We aimed to discuss the clinical and radiological features of SCD in the literature review and emphasize the importance of early diagnosis and treatment.

\section{CASE REPORT}

A 62-year-old male, who was admitted to the outpatient clinic complaining of a difficulty walking,

Corresponding author / İletişim adresi: Feyza Ünlü Özkan, MD. Fatih Sultan Mehmet Eğitim ve Araştırma Hastanesi, Fiziksel Tıp ve Rehabilitasyon Kliniği, 34752 İçerenköy, Ataşehir, İstanbul, Turkey. e-mail / e-posta: feyzamd@yahoo.com 
weakness in the legs and tingling of hands and feet. His past medical history revealed that he was hospitalized in the neurology clinic with the complaint of sensory disturbance in the legs two years prior. No abnormalities were detected in cranial and spinal vertebral MRIs and cerebrospinal fluid analysis during diagnostic work-up. Vitamin B12 deficiency was detected and intramuscular vitamin B12 treatment was initiated. At that time his symptoms improved and full recovery was achieved within weeks of his discharge from the hospital. He admitted that he discontinued the treatment a few months after recovery from his symptoms. He had no coexisting chronic or metabolic disorders. He had chronically consumed alcohol for 15 years and he was a smoker (2 pack/day) for 25 years. Physical examination revealed weakness in the lower extremities. Manuel muscle testing of bilateral iliopsoas, quadriceps, tibialis anterior, gastrocnemius and hamstring muscles were $3 / 5$. No muscle weakness was detected in the upper extremities. Deep tendon reflexes were normoactive in the upper extremities whereas patella and Achilles reflexes were hyperactive with bilaterally extensor plantar responses. Hip adductor and knee flexor spasticity was detected. He had position and vibration loss in all extremities which was more prominent in the legs. Sensory examination revealed sensory disturbances in the hands and feet. He could walk with the assistance of two people; Romberg test could not be performed. Mild dementia was detected (Mini mental test score $=22$ ). Laboratory tests showed mild anemia (Hb: $11.9 \mathrm{~g} / \mathrm{dL}$ Htc: 35.8 ) with normal mean corpuscular volume (MCV: $82.6 \mathrm{fL}$ ). Acute phase reactants, serum electrolytes, liver and kidney function tests were within normal range. Vitamin B12 was lower than $50 \mathrm{pg} / \mathrm{mL}$ (normal range: $126-505 \mathrm{pg} / \mathrm{mL}$ ) and folic acid level was normal ( $>20 \mathrm{ng} / \mathrm{mL}$ ). Electrophysiologic examination revealed normal nerve conduction studies and needle electromyography examination. The patient was sent to a consultation with internal medicine and neurology clinics. Abdominal ultrasonography (USG), blood smear, thoracic, cervical and cranial MRIs were performed. Abdominal USG, cranial and spinal MRIs were normal and blood smear findings were consistent with megaloblastic anemia. The vitamin B12 deficiency was attributed to chronic alcohol consumption and the patient was diagnosed as SCD due to chronic alcohol consumption and vitamin B12 replacement treatment was initiated. Intramuscular B12 injections were applied daily $(1000 \mathrm{mcg} /$ day $)$ for five days and once a week for five weeks. On the $10^{\text {th }}$ day of replacement treatment, vitamin B12 level was measured as $1007 \mathrm{pg} \backslash \mathrm{mL}$. He had been in an inpatient rehabilitation program for six weeks, including lower extremity strengthening, proprioception and balance exercises. Lower extremity muscle strength improved and he is now walking with the aid of a walker. He was informed about the importance of adherence to the replacement therapy and he is on monthly intramuscular vitamin B12 injections. A written informed consent was obtained from the patient.

\section{DISCUSSION}

The most common causes of vitamin B12 deficiency are gastritis, pernicious anemia, impaired gastric surgery, inflammatory bowel disease, pancreatic insufficiency, medications (proton pump inhibitors, colchicine, neomycin, H2-receptor antagonists, metformin, cholestyramine, anticonvulsants), inadequate intake (vegetarian diet) and nitric oxide exposure or genetic disorders like transcobalamin II deficiency. ${ }^{[1,2]}$ The major sources of vitamin B12 are animal proteins, mainly meat and eggs. The recommended daily intake is $2.4 \mu \mathrm{g}$ for adults, 2.6 for pregnant women, $2.8 \mu \mathrm{g}$ for lactating women and $1.5-2 \mu \mathrm{g}$ for children up to 18 years. Since a vegetarian diet supplies no more than $0.5 \mu \mathrm{g} /$ day of vitamin $\mathrm{B} 12$, most vegetarians are at risk for vitamin $\mathrm{B} 12$ deficiency. ${ }^{[1,3]}$ Besides vegetarians, the elderly, alcoholics, malnourished persons, patients with gastrointestinal diseases and patients with aforementioned medications are at risk for vitamin B12 deficiency. Common laboratory findings of vitamin B12 deficiency is macrocytosis with or without anemia and hypersegmented neutrophils. Megaloblastic anemia is a common early symptom leading to diagnosis, although neurological symptoms may occur in the absence of hematological abnormalities. ${ }^{[4,5]}$ Although vitamin B12 cutoff values vary for each laboratory, serum values of less than $200 \mathrm{pg} / \mathrm{mL}$ is defined as vitamin B12 deficiency. ${ }^{[6,7]}$ Older adults with vitamin B12 levels between 200 and $500 \mathrm{pg} / \mathrm{mL}$ might also have symptoms. Laboratory reevaluation at about two to three months by repeating the complete blood count and vitamin B12 level is recommended during follow-up. ${ }^{[7]}$

The neurological syndromes associated with vitamin B12 deficiency are myelopathy, neuropathy, neuropsychiatric abnormalities, and less often, optic atrophy. Pathology is demyelination involving the dorsal columns spreading in the cranial and caudal directions and into the lateral columns. Therefore, 
myelopathy is called subacute combined degeneration. Pathophysiology of demyelination and why specific tracts are more affected than others is not certain. ${ }^{[5,8]}$ The posterior or posterolateral column is the part most affected, especially at the cervicodorsal level. The initial symptoms are paresthesias in the hands and feet, usually symmetrical. Clinical manifestations may progress to impair position sense and vibration, gait ataxia and up to spastic paraparesis or tetraparesis if left untreated. There may be irritability, apathy, confusion, depression, dementia and visual impairment. ${ }^{[3,8]}$ Findings on physical examination are loss or disturbance of vibration and joint position sense, weakness, spasticity, hyperreflexia and extensor plantar responses. The basis of the diagnosis is physical examination and laboratory findings.

Subsequently, our patient had symptoms of posterior and lateral column involvement, with loss of vibration and position sense which was more prominent in the legs. Weakness in the lower extremities, spasticity, hyperactive patella and Achilles reflex and extensor plantar response presented delayed onset. Bilateral findings of motor and sensory involvement in our patient were consistent with the usual symmetrical involvement in SCD. Neuropsychiatric symptoms of SCD like irritability, apathy, drowsiness or confusion were not present in our patient, only mild dementia was detected. Optic neuropathy is a rare manifestation of vitamin B12 deficiency which is occasionally seen in advanced cases and characterized by symmetric, painless and progressive visual loss. ${ }^{[1,8]}$ Our patient had no symptoms or signs of visual involvement.

The hematologic changes especially megaloblastic anemia, are not reliable markers for vitamin B12 deficiency. A quarter of patients with neurologic findings have normal blood count; hematocrit is normal in $27.4 \%$ and $\mathrm{MCV}$ is normal in $23 \%{ }^{[4]}$ Therefore serum B12 level should be evaluated in any patient with sensory symptoms or weakness. Our patient had mild anemia with normal MCV but the findings of the blood smear were consistent with megaloblastic anemia and his former blood count in the neurology clinic also showed features of megaloblastic anemia (Hb: $10.5 \mathrm{~g} / \mathrm{dL}$, MCV: $116.5 \mathrm{pL}$ ). Previous treatment provided normalization in the blood count but cessation of vitamin B12 intake lead to neurologic symptoms before alterations in MCV and hemoglobin level. This situation is consistent with the literature where neurological symptoms in the absence of hematological abnormalities were reported..$^{[4,5]}$ The differential diagnosis for progressive spastic paraplegia includes degenerative, demyelinating, infectious, inflammatory, neoplastic, nutritional and vascular disorders. ${ }^{[9,10]}$ Normal abdominal USG, cranial and spinal MRI's and history of chronic alcoholism provided the diagnosis of SCD due to chronic alcohol intake.

The MRI findings of the spinal cord in SCD are high signal intensity on $\mathrm{T}_{2}$-weighted images within the dorsal or lateral column. The abnormal signal intensity is particularly prominent in the dorsal columns which is a distinguishing feature of SCD imaging. ${ }^{[10,11]}$ The differential diagnosis of an intramedullary lesion includes demyelinating disorders (multiple sclerosis), infectious causes (HIV vacuolar myelopathy and herpes viruses), inflammatory processes (sarcoidosis), ischemia and neoplasms. Brain lesions of vitamin B12 deficiency over the medulla oblongata, pons, mesencephalon and crus cerebelli have also been reported. ${ }^{[12]}$ The lesions observed in the spinal cord disappear a few months after vitamin B12 treatment. Although these hyperintense $\mathrm{T}_{2}$ lesions on MRI are common not all patients with SCD have pathological changes on imaging. ${ }^{[1]]}$ We were also unable to detect any lesions on spinal and cranial MRI in our patient. Previous MRI sections of spinal column and brain were reevaluated by a radiologist and no particular findings related to SCD was detected in previous or control MRIs.

Classical treatment protocol for vitamin B12 deficiency is $1 \mathrm{mg} /$ day of vitamin B12 given intramuscularly for a week, followed by $1 \mathrm{mg} /$ week for four weeks and then $1 \mathrm{mg} /$ month for the rest of the patient's life. Obviously, supplemental therapy should be started after the vitamin deficiency has been established and the etiology is thoroughly investigated. Normalization of the complete blood count requires about eight weeks of therapy, ${ }^{[1]}$ laboratory reevaluation at about two to three months by repeating the complete blood count and vitamin B12 level is recommended. The literature about the compliance of patients and rate of adherence to vitamin B12 replacement therapy is lacking. Informing the patients about the seriousness and irreversible consequences of non-adherence is crucial.

Our patient had given up the injections months after his discharge from the neurology clinic. Almost a year later his symptoms began again and initial symptoms of sensory disturbance progressed to paraparesis and difficulty walking. Patients should be informed about the life-long supplementation of vitamin B12 and cautioned about the outcomes of discontinuation. 
Symptoms of SCD are usually reversible if diagnosed and treated early. However, diagnostic delay or discontinuation of therapy may result in permanent irreversible injury to the spinal cord with disabling neurological impairments.

In conclusion, vitamin B12 deficiency should be considered in all patients with sensory symptoms, weakness and gait disturbance. Prompt diagnosis of SCD and early treatment could avoid irreversible neurologic damage and prevent disability. Parenteral replacement therapy should be initiated as soon as possible and followed by a careful, life-long follow-up with patients. Adherence to life-long treatment should also be emphasized in order to prevent irreversible neurologic damage, progression or recurrences.

\section{Declaration of conflicting interests}

The authors declared no conflicts of interest with respect to the authorship and/or publication of this article.

\section{Funding}

The authors received no financial support for the research and/or authorship of this article.

\section{REFERENCES}

1. Briani C, Dalla Torre C, Citton V, Manara R, Pompanin S, Binotto G, et al. Cobalamin deficiency: clinical picture and radiological findings. Nutrients 2013;5:4521-39.

2. Cabrerizo-García JL, Sebastián-Royo M, Montes N, ZalbaEtayo B. Subacute combined spinal cord degeneration and pancytopenia secondary to severe vitamin B12 deficiency. Sao Paulo Med J 2012;130:259-62.

3. Green R, Kinsella LJ. Current concepts in the diagnosis of cobalamin deficiency. Neurology 1995;45:1435-40.

4. Healton EB, Savage DG, Brust JC, Garrett TJ, Lindenbaum J. Neurologic aspects of cobalamin deficiency. Medicine (Baltimore) 1991;70:229-45.

5. Lindenbaum J, Healton EB, Savage DG, Brust JC, Garrett TJ, Podell ER, et al. Neuropsychiatric disorders caused by cobalamin deficiency in the absence of anemia or macrocytosis. N Engl J Med 1988;318:1720-8.

6. Matchar DB, McCrory DC, Millington DS, Feussner JR. Performance of the serum cobalamin assay for diagnosis of cobalamin deficiency. Am J Med Sci 1994;308:276-83.

7. Berg RL, Shaw GR. Laboratory evaluation for vitamin B12 deficiency: the case for cascade testing. Clin Med Res 2013;11:7-15.

8. Larner AJ. Visual failure caused by vitamin B12 deficiency optic neuropathy. Int J Clin Pract 2004;58:977-8.

9. Bou-Haidar P, Peduto AJ, Karunaratne N. Differential diagnosis of T2 hyperintense spinal cord lesions: part B. J Med Imaging Radiat Oncol 2009;53:152-9.

10. Ravina B, Loevner LA, Bank W. MR findings in subacute combined degeneration of the spinal cord: a case of reversible cervical myelopathy. AJR Am J Roentgenol 2000;174:863-5.

11. Larner AJ, Zeman AZ, Allen CM, Antoun NM. MRI appearances in subacute combined degeneration of the spinal cord due to vitamin B12 deficiency. J Neurol Neurosurg Psychiatry 1997;62:99-100.

12. Katsaros VK, Glocker FX, Hemmer B, Schumacher M. MRI of spinal cord and brain lesions in subacute combined degeneration. Neuroradiology 1998;40:716-9. 